\title{
The Spatial and Temporal Characteristics of Cultivated Land Utilization in Chengdu-Chongqing Urban Agglomeration
}

\author{
Xiao Yuejie, Tang Honga, ${ }^{*}$ \\ (College of Management, Sichuan Agricultural University, 611130 ,Chengdu,China)
}

\begin{abstract}
Based on the data of economic, social and ecological benefits of cultivated land in Chengdu-Chongqing urban agglomeration from 2005 to 2014, this paper applies multi-factor comprehensive evaluation model and ArcGIS spatial analysis method to explore the dynamic change and regional difference of the cultivated land use efficiency of Chengdu-Chongqing urban agglomeration. The results showed that the overall efficiency index of cultivated land utilization in Chengdu-Chongqing urban agglomeration, except the economic benefit index, is rising steadily year by year. Among them, the fluctuation of ecological benefit is the most significant, and in 2010 and 2013, there appeared obvious trough. The utilization efficiency of cultivated land in different cities is relatively large, and in terms of distribution pattern, northwest is high, southeast low. The farmland utilization comprehensive efficiency high value district is Ziyang city, Chengdu city and Meishan city. In the future, the Chengdu-Chongqing urban agglomeration should pay more attention to the improvement of agro-ecological environment, control the application of pesticides and fertilizers, and promote the coordinated development of the economic, social and ecological benefits of cultivated land.
\end{abstract}

\section{Introduction}

Cultivated land resources, as important basic production materials, have various utilization values for human society, which are irreplaceable labor objects, production factors and space places in agricultural production ${ }^{[1-3]}$. In recent years, with the raipid development of urbanization and industrialization in our country, the non-agricultural occupation of cultivated land continues to increase, the quality of cultivated land is destroyed, the reserve cultivated land resources are decreasing, and the pressure of cultivated land resources increases ${ }^{[4-5]}$. It is of great significance to protect the national food security and regional sustainable development by exploring the connotation of cultivated land and improving the utilization efficiency of cultivated $\operatorname{land}^{[6]}$. In foreign countries, the study on the utilization of cultivated land began earlier. According to the principles and methods determined by the agricultural typology committee, the Polish agricultural geographer Kostowicki divided the world agriculture into 6 primary types and 25 secondary types of 93 types $^{[7]}$. Herdt et al. proposed to measure the sustainable development ability of agricultural system from three aspects: ecological benefit, social benefit and economic benefit ${ }^{[8-9]}$. The domestic research is based on the economic, social and ecological aspects of the system, using the main ingredient analysis, the cluster analysis, and the correlation analysis to explore the cultivated land efficiency of the above prefecture-level cities in the eastern and central regions. Few scholars pay attention to the evolvement and spatial differentiation of cultivated land in the western urban agglomeration. As the main area of the strategic core area and new-type urbanization of the national economic development, the major urban agglomeration bears the burden of transferring the center of the world economy. As the most competitive urban agglomeration in the west, Chengdu-Chongqing urban agglomeration plays an important role in promoting the development of the western region and the construction of the Yangtze river economic belt. Based on this, this study builds an index system from the economic, social and ecological aspects, and analyzes the spatial and temporal characteristics of the cultivated land use benefit of Chengdu-Chongqing urban agglomeration, with a view to providing reference for the rational and efficient utilization of cultivated land resources.

\section{Overview of research area}

Located in the southwest of China, serving as an important country, urban population and industrial concentration area in China, Chengdu-Chongqing urban agglomeration is important to lead the western region to accelerate development, upgrade the inland opening level, and strengthen the construction of One Belt And One Road and the development of the Yangtze river economic belt. According to the Chengdu-Chongqing urban agglomeration development plan for 2016, 
Chengdu-Chongqing urban agglomeration in the specific scope includes Yuzhong district in Chongqing, Wanzhou, Qianjiang, Peiling and other 27 districts (counties), parts of Kai county and Yunyang as well as s 15 cities in Sichuan province such as Chengdu, Zigong, Luzhou and Deyang. Chengdu-Chongqing urban agglomeration is a complex terrain with diverse landform, uneven distribution of cultivated land and obvious difference in quality space. In 2014, the arable land area was 490.47 million $\mathrm{hm}^{2}$, accounting for $4.03 \%$ of the total area. For a long time, the development of arable land and crop production in the region is mainly relying on chemical resources inputs such as fertilizers, pesticides, which will inevitably put greater pressure on resources and environment as well as restrict the sustainable development of green agriculture. The analysis of the spatial and temporal characteristics of the cultivated land use benefit in the Chongqing urban agglomeration is conducive to the rational and efficient utilization of cultivated land resources.

\section{Data sources and research methods}

\subsection{Construction of index system and data source}

The utilization efficiency of cultivated land involves three aspects: economic, social and ecological benefit. Economic benefit refers to the investment of cultivated land funds, labor and science and technology, which is reflected in the increase of cultivated land production, the decrease of production cost and the improvement of production efficiency. The social benefit is the guarantee level for social food security and social stability in the utilization of cultivated land. Ecological benefit emphasizes the influence of cultivated land use on water resources, soil and other ecological environment. In order to rationally, comprehensively and scientifically evaluate the utilization efficiency of cultivated land, following the principles of comprehensiveness, systematicness and operability, refering to relevant research results and combining the actual situation of Chengdu city group and the availability of data, we analyze and choose 5 economic benefit indexes such as agricultural labor productivity, 5 social benefit indicators such as per capita net income of farmers as well as forest coverage rate and other four ecological benefit evaluation index systems. The positive indicator indicates positive positive effect on regional cultivated land use benefit, the bigger the better, whereas the reverse indicator indicates that it inhibits the utilization efficiency of cultivated land and the smaller the better. Based on the 16 prefecture-level cities in Chengdu-Chongqing city, the index data mainly came from the statistical yearbook of Sichuan province Chongqing statistical yearbook, China urban statistical yearbook from 2005 to 2014,, statistical bulletin of national economic and social development of each city, and relevant government reports.
Table 1. Evaluation index system of cultivated land use benefit

\begin{tabular}{|c|c|c|c|c|}
\hline $\begin{array}{l}\text { rule } \\
\text { layer }\end{array}$ & index layer & unit & $\begin{array}{c}\text { natu } \\
\text { re }\end{array}$ & meaning \\
\hline \multirow{5}{*}{$\begin{array}{l}\text { econo } \\
\text { mic } \\
\text { benefi } \\
\text { ts }\end{array}$} & $\begin{array}{l}\text { agricultural } \\
\text { labor } \\
\text { productivity }\end{array}$ & yuan/person & + & $\begin{array}{l}\text { the total GDP of } \\
\text { the first industry/ } \\
\text { the first industry } \\
\text { working } \\
\text { population }\end{array}$ \\
\hline & $\begin{array}{c}\text { land value of } \\
\text { agricultural } \\
\text { land }\end{array}$ & $\begin{array}{l}\text { ten thousand } \\
\text { yuan } / \mathrm{hm}^{2}\end{array}$ & + & $\begin{array}{l}\text { gross value of } \\
\text { agricultural } \\
\text { output /total area } \\
\text { of cultivated land }\end{array}$ \\
\hline & $\begin{array}{c}\text { degree of } \\
\text { agricultural } \\
\text { mechanization }\end{array}$ & $\mathrm{kw} / \mathrm{hm}^{2}$ & + & $\begin{array}{c}\text { agricultural } \\
\text { machinery total } \\
\text { power/cultivated } \\
\text { area }\end{array}$ \\
\hline & $\begin{array}{c}\text { per capita } \\
\text { agricultural } \\
\text { output }\end{array}$ & yuan/person & + & $\begin{array}{c}\text { total agricultural } \\
\text { output/total } \\
\text { population }\end{array}$ \\
\hline & $\begin{array}{c}\text { return on } \\
\text { investment in } \\
\text { agricultural } \\
\text { fixed assets }\end{array}$ & $\%$ & + & $\begin{array}{l}\text { total agricultural } \\
\text { output/agricultura } \\
1 \text { fixed investmen }\end{array}$ \\
\hline \multirow{5}{*}{$\begin{array}{l}\text { social } \\
\text { benefi } \\
\text { ts }\end{array}$} & $\begin{array}{l}\text { the per capita } \\
\text { net income of } \\
\text { farmers }\end{array}$ & yuan/person & + & $\begin{array}{l}\text { It reflects the } \\
\text { average income } \\
\text { of rural residents. }\end{array}$ \\
\hline & $\begin{array}{l}\text { per capita food } \\
\text { production }\end{array}$ & $\mathrm{kg} /$ person & + & $\begin{array}{l}\text { total grain } \\
\text { output/total } \\
\text { population }\end{array}$ \\
\hline & $\begin{array}{l}\text { food safety } \\
\text { factor }\end{array}$ & dimensionless & + & $\begin{array}{c}\text { total grain } \\
\text { output/total } \\
\text { population } \\
\text { /400kg }\end{array}$ \\
\hline & $\begin{array}{c}\text { per capita } \\
\text { cultivated area }\end{array}$ & person $/ \mathrm{hm}^{2}$ & + & $\begin{array}{l}\text { total farmland } \\
\text { area/total } \\
\text { population }\end{array}$ \\
\hline & $\begin{array}{l}\text { urbanization } \\
\text { rate }\end{array}$ & dimensionless & + & $\begin{array}{l}\text { non-agricultural } \\
\text { population/total } \\
\text { population }\end{array}$ \\
\hline \multirow{5}{*}{$\begin{array}{l}\text { ecolog } \\
\text { ical } \\
\text { benefi } \\
\text { ts }\end{array}$} & $\begin{array}{c}\text { forest coverage } \\
\text { rate }\end{array}$ & $\%$ & + & greening degree \\
\hline & $\begin{array}{l}\text { fertilizer usage } \\
\text { per unit area }\end{array}$ & $\mathrm{kg} / \mathrm{hm}^{2}$ & - & $\begin{array}{c}\text { amount of } \\
\text { fertilizer use } \\
\text { /total area of } \\
\text { cultivated land }\end{array}$ \\
\hline & $\begin{array}{c}\text { effective } \\
\text { irrigation index }\end{array}$ & $\%$ & + & $\begin{array}{l}\text { effective irrigated } \\
\text { area/total area of } \\
\text { cultivated land }\end{array}$ \\
\hline & $\begin{array}{c}\text { energy } \\
\text { consumption } \\
\text { of ten thousand } \\
\text { yuan output } \\
\text { value }\end{array}$ & $\begin{array}{c}\mathrm{kw} / \mathrm{ten} \\
\text { thousand yuan }\end{array}$ & - & $\begin{array}{c}\text { agricultural } \\
\text { electricity/agricul } \\
\text { tural output value }\end{array}$ \\
\hline & $\begin{array}{l}\text { multiple crop } \\
\text { index }\end{array}$ & dimensionless & + & $\begin{array}{c}\text { total annual crop } \\
\text { sown } \\
\text { area/cultivated } \\
\text { area } \\
\end{array}$ \\
\hline
\end{tabular}

\subsection{Research methods}

Entropy method is an objective weighting method to determine the weight of each index based on the information provided by the observation value. According to the original information derived from the objective environment, it determines the weight of indicators by analyzing the amount of information provided by each indicator, which avoids the deviation caused by subjective factors to a certain extent, and can obtain more scientific and reasonable evaluation results. The calculation steps are as follows:

Based on the original value of each index, the standardization process was adopted to eliminate the dimension, and the standardized value was obtained, which was used as the evaluation standard of the index system. The data is standardized by the method of extreme difference transformation. 
Positive indicators: $y_{i j}=\frac{x_{i j}-b_{i j}}{a_{i j}-b_{i j}}$; Reverse index:

$$
y_{i j}=\frac{a_{i j}-X_{i j}}{a_{i j}-b_{i j}}
$$

(1) In the formula: $y_{i j}$ is the number after the dimensionless treatment. $x_{i j}$ refers to the actual value of the $\mathrm{i}$-th index of j. $a_{i j}$ is the maximum value of the $\mathrm{i}$-th index. $B_{i j}$ is the minimum for the $\mathrm{i}$-th index.

(2) Calculating the information entropy Ei of the i-th index in each year, as shown in formula (2) and (3) In the formula: $P_{i j}$ is the weight of the $\mathrm{i}$-th index value in year $\mathrm{j}$, and $y_{i j}$ is the standardized value.

$$
E_{i}=[-1 / \ln (n)] \sum_{i=1}^{m} p_{i j} \ln \left(p_{i j}\right)
$$

Among them:

$$
P_{i j}=\frac{y_{i j}}{\sum_{i=1}^{m} y_{i j}}
$$

(3) Calculating single factor weight $B_{i}$ and combination weight $W_{i}$.

$$
B i=\frac{1-E_{i}}{\sum_{i=1}^{m}\left(1-E_{i}\right)} ; W i=\frac{1-E_{i}}{\sum_{i=1}^{m}\left(1-E_{i}\right)}
$$

(4) Evaluation model of cultivated land use benefit:

Taking into account the later drawing, it is convenient to observe and convert the standardized processing value into the index score: $Q_{i}=y_{i j} \times 10+100$. The score and index weight were calculated according to the standardized data of each index and the evaluation model of cultivated land use benefit was established by multi-factor comprehensive evaluation method. $P=$ $\sum_{i=1}^{15} Q_{i} W_{i} ; E=\sum_{j=1}^{5} Q_{i} B_{i} ; S=\sum_{j=6}^{10} Q_{i} B_{i} ; F=$ $\sum_{j=11}^{15} Q_{i} B_{i}$. Among them, $\mathrm{P}$ is the comprehensive benefit index; $\mathrm{E}$ is the economic benefit index; $\mathrm{S}$ is the social benefit index; $\mathrm{F}$ is the ecological benefit index; $Q i$ is the score of the $\mathrm{i}$-th index; $W_{i}$ is the combined weights for each indicator, $\sum W_{i}=1 ; B_{i}$ is single factor weight, $\sum B_{i}=1$.

\section{Result analysis}

\subsection{Evolution of cultivated land use benefit in Chengdu-Chongqing urban agglomeration}

As can be seen from figure 1, the cultivated land use of the Chengdu-Chongqing urban agglomeration in 2005-2014 shows a steady increase in the economic performance index, and the social, ecological and comprehensive benefit indexes all show the trend of fluctuation. Among them, the fluctuation of ecological benefit is the most significant, and in 2010 and 2013, there appeared obvious trough.

The economic benefit of cultivated land utilization is the core of the comprehensive utilization efficiency of cultivated land, and the improvement of economic benefit will contribute to the improvement of social demand and the improvement of cultivated land ecological environment. The economic efficiency index of cultivated land use increased year by year, rising from 100.5240 in 2005 to 109.0160 in 2014. In recent years, the Chengdu-Chongqing urban agglomeration actively adapt to the new normal economic development, speed up the transformation of the pattern of economic development, promote the transformation and upgrading of economic structure, and with the national average gap is narrowing, agricultural GDP per capita increased nearly three times from 2783.7402 yuan/people in 2005 to 7595.3288 yuan/person in 2014. As the key construction area of western talent highland, Chengdu-Chongqing urban agglomeration has been actively cultivating and introducing high-end science and technology innovation talents in recent years, carrying out industry-university-research integration and improving agricultural technology. And agricultural mechanization increased from 6.14 percent in 2005 to 11.14 percent in 2014. The progress of technological efficiency has unleashed an excess of labor, which has led to a remarkable increase in agricultural productivity. At the same time, the project was actively promoted for the prevention and control of water pollution and soil environment quality improvement, and the rate of return on agricultural investment increased by $8.23 \%$ over 2005.

Cultivated land use social benefit index showed a trend of greater volatility and there is an obvious decline in 2006. The reason is that in August 2006, there are more precipitation in the hinterland of Chengdu-Chongqing urban agglomeration, the main river water level rises seriously, the local farmland is flooded, and the food production is directly threatened. In 2006, the per capita grain output decreased by $17.76 \%$ compared with the previous year. In order to speed up the development of modern agriculture, Chengdu-Chongqing urban agglomeration has actively implemented grain production capacity improvement project, built functional area and core area of grain production, promoted the creation of grain yield and green production mode, and the grain output per unit cultivated land was guaranteed. With the rapid development of economy and the expansion of urban scale, the urbanization rate increased from $33.01 \%$ in 2005 to $45.71 \%$ in 2014 , with an average annual growth rate of $4.28 \%$, and the average annual growth rate of rural per capita net income was $24.32 \%$.

The cultivated land use ecological benefit is related to the sustainable development of cultivated land use, and the ecological benefit index of the cultivated land utilization in the Chengdu-Chongqing urban agglomeration in 2005-2014 has obviously decreased and is not rising steadily. In 2005-2009, Chengdu-Chongqing urban agglomeration of farmland ecological environment conditions are relatively good, the early stage of the ecological index is significantly higher than the economic benefit, social benefit and comprehensive benefit. However, the increase in grain yield was accompanied by the large-scale disordered use of fertilizers and pesticides, resulting in the obvious trough in 2010 and 2013. In 2011-2012, the ecological efficiency index of cultivated land increased slightly, and the gradual reduction in the energy consumption of the $\$ 10,000$ has increased the cultivated land use ecological benefit level. With the development of ecological civilization, resource-saving and environment-friendly society, the forest ecological system has been effectively 
protected, and the forest coverage rate has increased from $36.55 \%$ in 2005 to $43.23 \%$ in 2014 .

Comprehensive effect fluctuates upward. In 2004, the state began to increase the strength of agriculture, agriculture, rural areas and farmers. In 2006, the agricultural tax was abolished, and the farmers' burden was reduced year by year, and the economic and social benefits of cultivated land were improved. In 2010 and 2013, there was a small downward trend in overall efficiency. In recent years, per capita arable land and per capita grain output increase, per capita net income of farmers increased significantly, the social benefit is greatly improved; nevertheless, the productivity and utilization rate of new cultivated land tends to be low, so the ratio of the compound index and the effective irrigation area decreases, resulting in a sharp decline in the ecological benefit of cultivated land use in a short time. At the same time, with the development of Chengdu-Chongqing urban agglomeration, the project of "reconstructing a Dujiangyan irrigation district" was carried out, and the large and medium-sized reservoirs, such as the Jinfoshan of Nanchuan and the Jingguankou were implemented, and the water supply capacity was effectively guaranteed. The agricultural science and technology level, the improvement of the comprehensive quality of farmers and the improvement of the agricultural ecological environment have led to the overall increase in the overall efficiency.

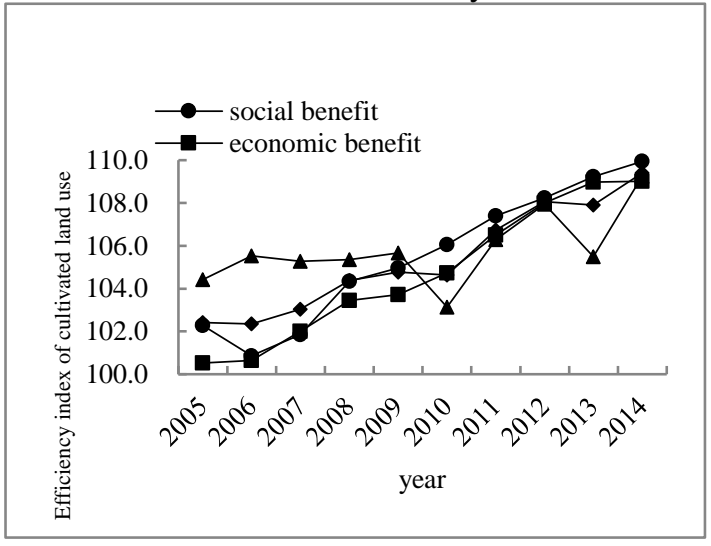

Figure 1. Changes of cultivated land use efficiency index of Chengdu-Chongqing urban agglomeration from 2005 to 2014

\subsection{The spatial differences of the utilization efficiency of cultivated land in Chengdu-Chongqing urban agglomeration}

Based on the index of cultivated land utilization efficiency in cities of Chengdu-Chongqing city in 2014, using thematic map of ArcGIS10.2 software display the spatial distribution map of the cultivated land utilization efficiency of Chengdu-Chongqing agglomeration. Cultivated land utilization benefit of Chengdu-Chongqing urban agglomeration properties data generation space distribution, the distribution differences of economic benefits, social benefits, ecological benefits and comprehensive benefits in regional space is studied. (figure 2 ).
The economic efficiency of cultivated land use in Chengdu-Chongqing urban agglomeration is different, and it has obvious regional characteristics. There are three cities with an economic efficiency index of less than 102.50. There are seven cities with economic benefit index between 102.51 and 103.00, and there are six in the market between 103.01 and 104.53. Compared with social and ecological benefits, cultivated land use economic benefit has the greatest impact on comprehensive benefit, while agricultural investment productivity and agricultural labor productivity have a great influence on the utilization of economic benefits of cultivated land. The city with high cultivated land use economic benefits is Deyang city, which is located is located in the city belt of chengde Mianle, and Neijiang city, which is a densely populated area in southern Sichuan and Nanchong city. The common characteristic of the three cities is that all have higher agricultural investment returns and per capita agricultural GDP. In 2014, the return on agricultural investment in Deyang city, Neijiang city and Nanchong city was $25.768 \%$, $17.934 \%$ and $17.906 \%$ respectively. The relative average value $(11.807 \%)$ was the absolute advantage. The city with low cultivated land use economic benefits is mainly Ya 'an, Zigong city in densely populated areas of southern Sichuan and Yibin city. The main reason is that the agricultural investment productivity, per capita agricultural GDP and agricultural labor productivity are relatively low, which is unfavorable to the improvement of the economic efficiency of cultivated land. As the basis of evaluation of cultivated land utilization benefit, with the acceleration of population and land urbanization, the economic benefit of cultivated land should not be limited to the increase of total output, but also the improvement of input and output efficiency.

The area of cultivated land use social benefit index above 105.00 is mainly concentrated in the Ziyang city, Deyang city and Meishan city, which are in the southwest of Chengdu-Chongqing urban agglomeration. The social benefit of cultivated land is mainly affected by factors such as per capita net income of farmers and urbanization level. It is found that the cultivated land use social benefit in the urban fringe of Chengdu city is much higher than that of other cities in Chengdu-Chongqing city, mainly because the per capita cultivated land area and per capita grain yield are relatively high. For example, in Ziyang, the per capita cultivated land area and per capita grain yield per capita in 2014 were 630.4277 people $/ \mathrm{hm} 2$ and $0.0756 \mathrm{~kg} /$ person respectively. The per capita cultivated land area exceeded the average level of $51.10 \%$, and the per capita grain yield exceeded the average level of $38.44 \%$. With the improvement of urbanization rate, the cultivated land in Chengdu and Chongqing, the central city of Chengdu-Chongqing development, will be reduced and grain output will be reduced accordingly. Therefore, its cultivated land use social benefit is relatively low. Due to the low per capita net income of farmers (9056 yuan), relatively extensive land use and low grain yield, Ya 'an city has become the lowest city in the city of Chengdu-Chongqing urban agglomeration with the land 
utilization social benefit

Deyang city is located in the Chengde Mianle city belt, and its cultivated land use comprehensive benefit and economic benefit are all in the top of the cities of Chengdu-Chongqing urban agglomeration, but its cultivated land use ecological efficiency index is only 102.96, which is mainly because in the process of agricultural modernization, the larger unit area of fertilizer use and the energy consumption of ten thousand yuan produce negative effects on the cultivated land ecological environment, which leads to the low ecological efficiency of cultivated land utilization in Deyang city. In 2014, the amount of fertilizer use and energy consumption of the unit area in Deyang city was $1048.3355 \mathrm{~kg} / \mathrm{hm} 2$ and $611.3894 \mathrm{kw} /$ ten thousand yuan respectively, which was $50.07 \%$ and 86.66 percent higher than the average level of Chengdu-Chongqing urban agglomeration. The acceleration of agricultural modernization will bring convenience to agricultural production and increase the efficiency of agricultural production, however, it should also reduce the influence of human factors on the cultivated land ecological environment, and avoid excessive use of fertilizers to bring pollution to the environment and excessive energy consumption. In this way, the demand for sustainable use of land can be adapt to the context of rapid urbanization.

The comprehensive benefit index of the cultivated land use in Chengdu-Chongqing urban agglomeration is the spatial distribution pattern of the northwest and the southeast, which is affected by the geographical difference of the geography and the difference between the agricultural economy and the level of technological development in each city. Cultivated land use benefit is greatly influenced by the economic benefit of cultivated land, and has obvious regionalism. The comprehensive benefit indexes of the cultivated land use in the cities of Ziyang city, Chengdu city and Meishan city were the highest, respectively $104.87,104.56$ and 104.51 , mainly because of the higher agricultural investment returns and per capita agricultural GDP of the three cities, which had a significant driving effect on the utilization of economic benefits of cultivated land. The comprehensive benefit of cultivated land use is the overall performance of cultivated land economy, society and ecological benefit and under the influence of all three. Therefore, we should pay attention to the coordinated development of economic, social and ecological environment, especially the improvement of the ecological benefits of cultivated land use, and avoid the extreme growth at the cost of destroying the ecological environment.

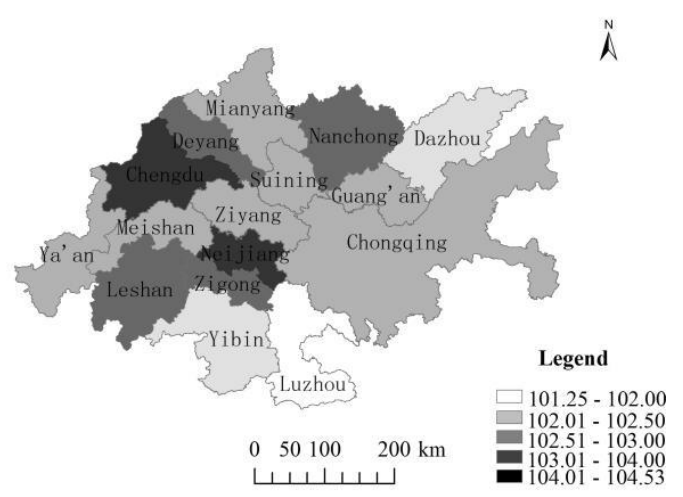

a.Economic benefit

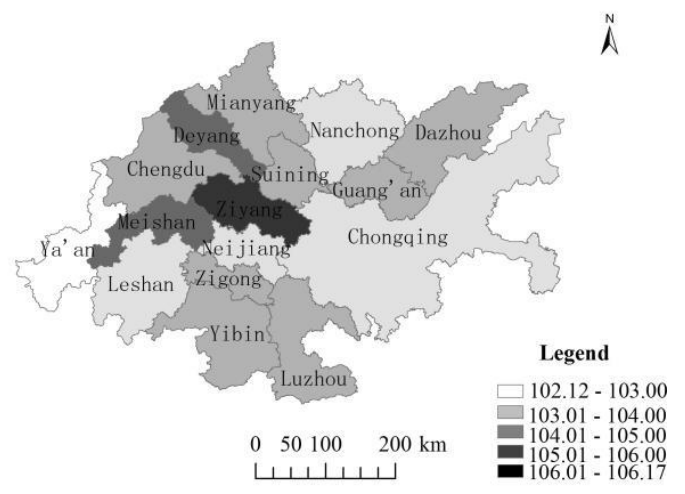

b.Social benefit

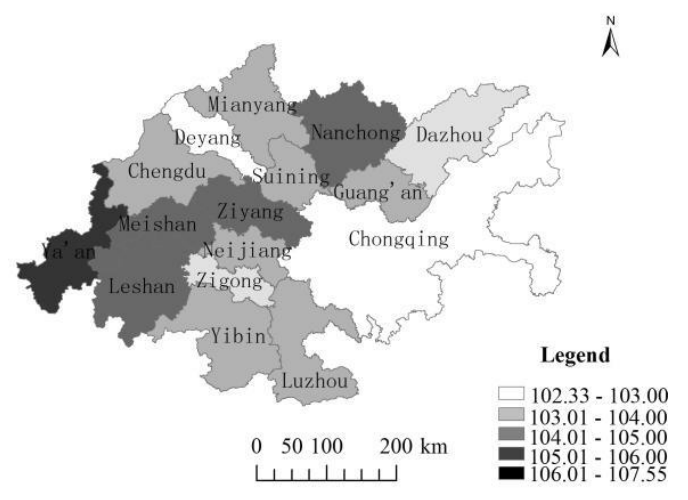

c.Ecological benefit

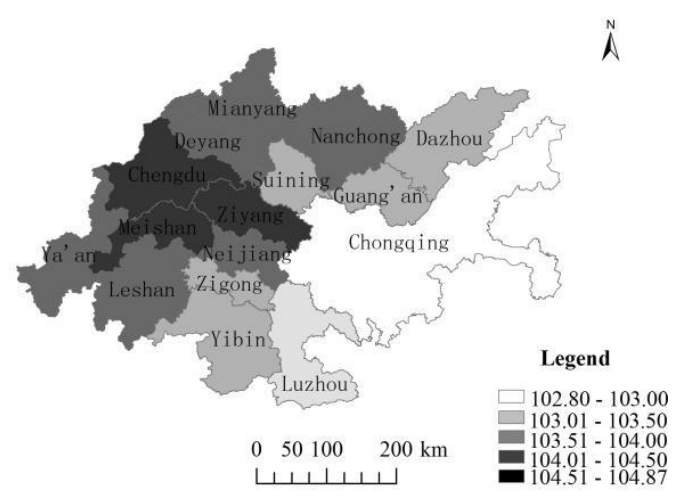

d.Comprehensive benefit

Fig.2 Spatial differentiation of cultivated land utilization efficiency index of Chengdu-Chongqing agglomeration 


\section{Conclusions and Discussions}

From 2005 to 2014, the cultivated land use in Chengdu-Chongqing urban agglomeration was steadily rising year by year except the economic benefit index, and the social, ecological and comprehensive benefit indexes all showed the trend of fluctuation. Among them, the fluctuation of ecological benefit is the most significant. In 2010 and 2013, there appeared obvious trough, mainly due to the large-scale disorganization of chemical fertilizers and pesticides. Over the last ten years, the increase in the utilization efficiency of cultivated land has been largely dependent on the growth of grain production, agricultural mechanization and the per capita net income of farmers as well as the reduction in energy consumption of ten thousand yuan output value.

The difference of cultivated land use benefit space of Chengdu-Chongqing urban agglomeration is significant, and there is a clear high northwest, southeast low spatial distribution form. The development of agricultural economy and technology in each city is uneven, and the economic benefit of cultivated land is relatively large. Agricultural investment productivity and agricultural labor productivity are the main factors that affect the economic benefit of cultivated land use. The area of cultivated land use social benefit index above 105.00 is mainly concentrated in Ziyang city, Deyang city and Meishan city in southwest of Chengdu-Chongqing urban agglomeration, which are mainly affected by the per capita net income of farmers and urbanization level. It can be seen that the cultivated land use technology and resource utilization efficiency of Chengdu-Chongqing urban agglomeration are unbalanced, and the agricultural output gap is large.

With the implementation of "One Belt And One Road" and the strategy of the Yangtze river economic belt, the development of the western region and the rapid development of economic and social development have put forward higher requirements for the efficiency of the utilization of resources of Chengdu-Chongqing urban agglomeration. In the future development of farmland utilization and protection policy, it is not realistic to attempt to increase the quantity of cultivated land and make a breakthrough. The focus should be on the improvement of cultivated land quality, the efficient intensive utilization of cultivated land and the protection of ecological environment. The Chengdu-Chongqing urban agglomeration should formulate corresponding regional cultivated land use planning according to the spatial difference of the utilization efficiency of cultivated land, and guide the coordinated development of regional economic, social and ecological benefits. By relying on scientific and technological progress, we will increase the yield of crops on grain, increase the efficiency of agricultural production, reduce the spatial difference of agricultural mechanization level and energy consumption, control the growth of pesticide and fertilizer application in the process of cultivated land use, increase the effective irrigation area of cultivated land, and improve the effective utilization rate of cultivated land resources.

\section{Acknowledgement}

This article is the Humanity and Social Science Youth Foundation of Ministry of Education Project, "Research on the Economic Co-development and Space Radiation Effect of Chengdu-Chongqing Urban Agglomeration"(project number: 17YJC630136) and "Study on Comprehensive Carrying Capacity of Urban Economy, Society and Environment and its Optimal Path from the Perspective of Complex System" (project number: 15YJC630081); Sichuan Education Department Humanities and Social Science Project (project number: 16SA0007) granted.

\section{References :}

1. Ren Ping, Wu Fenna, Zhou Jieming. China's "two Strictest" Land Management Systems: Theoretical Contradictions and Realistic Dilemmas, Economic Management, 2012, 34(08):173-182.

2. Liu Qiongfeng, Li Mingde, Duan Jiannan, Wu Haiyong. Study on Spatial and Temporal Variation of Cultivated Land Use in Hunan Province Based on GIS, Economic Geography, 2013, 33(09):142-147.

3. Li Qiao, Gu Guofeng, Yao Li, et al. Analysis on the Change of Cultivated Land Use Efficiency in Heilongjiang Reclamation, Resources and Environment of Arid Area, 2016, 30(04): 30-35.

4. Song Ge, Liang Haiou, Lin Jia, et al. Comprehensive Benefit Evaluation and Driving Force Analysis of Cultivated Land in Reclamation Area of Heilongjiang Province, Economic Geography, 2010, 30(05):835-840.

5. Li Jia, Lei Guoping, Liu Yang, et al. Evaluation on the Utilization Efficiency of Cultivated Land in Henan province, Soil and water conservation report,2013,33(03):318-324.

6. Wang Yingying, Chen Yufu. Evaluation on the Utilization Efficiency of Cultivated Land in Dezhou, Journal of Henan Agricultural University, 2011,51(02):274-281.

7. Todkari G U, Suryawanshi S P, Suryawanshi M V, et al. Agriculture landuse pattern in solapur district of Maharashtra, International Journal of Agriculture Sciences, 2010, 2( 2) : 1 -8.

8. Herdt A R, Byeongsu Kim A, Taton T A. Encapsulated magneticnanoparticles as supports for proteins and recyclable biocatalysts, Bioconjugate Chemistry, 2007, 18( 1) : 183 -189.

9. Vitousek P M, Naylor R, Crews T, et al. Nutrient imbalances inagricultural development $[\mathrm{J}]$. Science, 2009, 324 ( 5934) : $1519-1520$. 